Abstracta Iranicacta Iranica

Revue bibliographique pour le domaine irano-aryen

Volume 30 | 2010

Comptes rendus des publications de 2007

\title{
Le grand perturbateur : réflexions sur la question iranienne. Grasset, 2007, 216 p.
}

\section{Anicée Van Engeland}

\section{(2) OpenEdition}

10 Journals

Édition électronique

URL : http://journals.openedition.org/abstractairanica/38092

DOI : 10.4000/abstractairanica.38092

ISSN : 1961-960X

\section{Éditeur :}

CNRS (UMR 7528 Mondes iraniens et indiens), Éditions de l'IFRI

\section{Édition imprimée}

Date de publication : 8 avril 2010

ISSN : 0240-8910

\section{Référence électronique}

Anicée Van Engeland, « Le grand perturbateur : réflexions sur la question iranienne. Grasset, 2007, 216 p. », Abstracta Iranica [En ligne], Volume 30 | 2010, document 298, mis en ligne le 08 avril 2010, consulté le 26 septembre 2020. URL : http://journals.openedition.org/abstractairanica/38092 ; DOI : https://doi.org/10.4000/abstractairanica.38092

Ce document a été généré automatiquement le 26 septembre 2020.

Tous droits réservés 


\section{Le grand perturbateur : réflexions sur la question iranienne. Grasset, 2007, 216 \\ p.}

Anicée Van Engeland

1 L'Iran affiche son désir de devenir la puissance majeure du Moyen-Orient au XXI siècle. Le régime de Téhéran compte sur un bouleversement régional de grande ampleur qui dépasse les distinctions traditionnelles entre les Perses et les Arabes, ou entre les chiites et les sunnites. Pour étendre son influence et son pouvoir de coercition, Téhéran accorde un rôle majeur à son arme nucléaire, mais la présence iranienne s'étend aussi, de manière plus souterraine, à toutes les zones de crise de la région, qu'il s'agisse de l'Irak ou du Liban, de l'Asie centrale et du Caucase. L'A. s'interroge sur la nécessité d'imposer des règles écrites sur le nucléaire qui pourraient plus tard empêcher ou limiter la communauté internationale dans ses tentatives de contrôle de l'Iran.

INDEX

Thèmes : 13.1. Iran

\section{AUTEURS}

ANICÉE VAN ENGELAND

European University Institute - Florence 